\title{
Variability of Ruppia cirrhosa in two coastal lagoons with differing anthropogenic stresses
}

\author{
Gérard Pergent ${ }^{1}$, Vanina Pasqualini ${ }^{1}$, Christine \\ Pergent-Martini ${ }^{1}$, Lila Ferrat ${ }^{1}$ and Catherine \\ Fernandez ${ }^{2, \star}$ \\ ${ }^{1}$ University of Corsica, Faculty of Sciences, Equipe \\ Ecosystèmes Littoraux, BP 52, 20250 Corte, France \\ 2 University of Provence, IMEP UMR-CNRS 6116, \\ Centre St Jérôme, case 421, 13387 Marseille cedex 20, \\ France, e-mail: catherine.fernandez@up.univ-mrs.fr \\ * Corresponding author
}

\begin{abstract}
The dynamics of Ruppia cirrhosa were studied over two years in two coastal lagoons on the Corsican coast (France, Mediterranean Sea). The lagoons differed in type of eutrophication: (1) Biguglia lagoon (urban and industrial effluent, agriculture, runoff from catchment area) and (2) Santa Giulia lagoon (tourist pressure in summer). Spatio-temporal variability of $R$. cirrhosa occurrence was monitored on permanent transects. We also monitored temporal changes in density, aboveground/belowground biomass and organic matter. Most of the parameters studied along the transects show variations with season and site. Density and aboveground biomass of $R$. cirrhosa in Biguglia lagoon were lower when Ulva species were present. This may be related to differences in nutrient availability. During the first year of the study, rainfall was greater with concomitantly higher nutrient inputs, which may account for the higher values of measured parameters in the first year. The results suggest that environmental parameter variations affect the functioning of $R$. cirrhosa meadows.
\end{abstract}

Keywords: aquatic Magnoliophyta; Mediterranean Sea; monitoring; population dynamics; seagrasses; wetland.

\section{Introduction}

Aquatic macrophytes, and especially aquatic Magnoliophyta, are prominent components of numerous lagoon habitats (Millet and Guelorget 1993, Sfriso and Ghetti 1998, Menéndez 2002, Sfriso et al. 2002). These plants have essential ecological roles (Tamisier and Boudouresque 1994), and also have economic importance (Pearce and Crivelli 1994, Skinner and Zalewski 1995). They contribute to sedimentary balance and constitute a bioindicator of water quality (Succow and Reinhold 1978 in: Meriaux and Wattez 1980, Blandin 1986, Guilizzoni 1991). For many years, strong anthropogenic pressures (e.g., fishing, fish and shellfarming, industrialisation and urbanisation) have disturbed Mediterranean lagoon eco- systems and strongly jeopardise their future survival (Bacher et al. 1995, Bettinetti et al. 1996, De Casabianca et al. 1997, Deslous-Paoli et al. 1998, Kjerfve 2000). Many studies highlight the degradation of aquatic Magnoliophyta in response to these disturbances, especially Cymodocea nodosa (Ucria) Ascherson, Zostera marina Linneaus and Zostera noltii Hornemann (PérezLlorens and Niell 1993, Perez and Romero 1994, Philippart 1995, Auby and Labourg 1996, Vermaat and Verhagen 1996, De Casabianca et al. 1997, Sfriso and Ghetti 1998, Laugier et al. 1999, Plus et al. 2001). However, very few surveys deal with Ruppia cirrhosa (Petagna) Grande, an aquatic magnoliophyte of widespread occurrence in European coastal lagoon waters (Verhoeven 1980, Viarioli et al. 1997, Bachelet et al. 2000), especially in Mediterranean lagoons (Verhoeven 1975, Verhoeven and Van Vierssen 1978, Baroli et al. 1997, Pergent-Martini et al. 1997, Ribera et al. 1997, Menéndez et al. 2002, Agostini et al. 2003, Marzano et al. 2003). $R$. cirrhosa is common in large permanent water bodies, in which it is one of the rare macrophytes that survives and exhibits healthy growth in salinities above 20 psu (Verhoeven 1979). This climax species has extremely high resistance to variations in environmental conditions. We monitored seasonal variations of this species in two lagoons with different types of anthropogenic stress.

\section{Materials and methods}

The two lagoons chosen (Biguglia and Santa Giulia) are located along the eastern coast of Corsica (Mediterranean Sea; Figure 1). The environmental conditions vary between the lagoons: there is greater heterogeneity and human pressure in the Biguglia lagoon than in the Santa Giulia lagoon (Table 1). The Biguglia lagoon has been included in the Ramsar list (wetlands of international importance) since 1990, and has been listed as a natural reserve since 1994 (Decree no. 94-688 of August 9, 1994). It lies parallel to the sea over a distance of about $10 \mathrm{~km}$, and is separated from the sea by a lido (recreational beach) not more than $1 \mathrm{~km}$ wide (Figure 1). This mesohaline lagoon (Sacchi 1985, Table 1) communicates with the sea through channels at the north and south ends. There are strong inputs of fresh water in the northern part of the lagoon (e.g., $23-53 \times 10^{6} \mathrm{~m}^{3} \mathrm{y}^{-1}$ of surface waters; Frisoni and Dutrieux 1992). In the centre of the lagoon and on the landward shore, the substratum is a fine sediment, rich in organic silt. On the seaward shore, the substratum is more sandy, sometimes with shells (Agenc 1989). There is fish farming in the lagoon, with an annual mean production of $180 \mathrm{t}$ (Boulmer et al. 1997). Nutrient concentrations in this lagoon are higher than in 


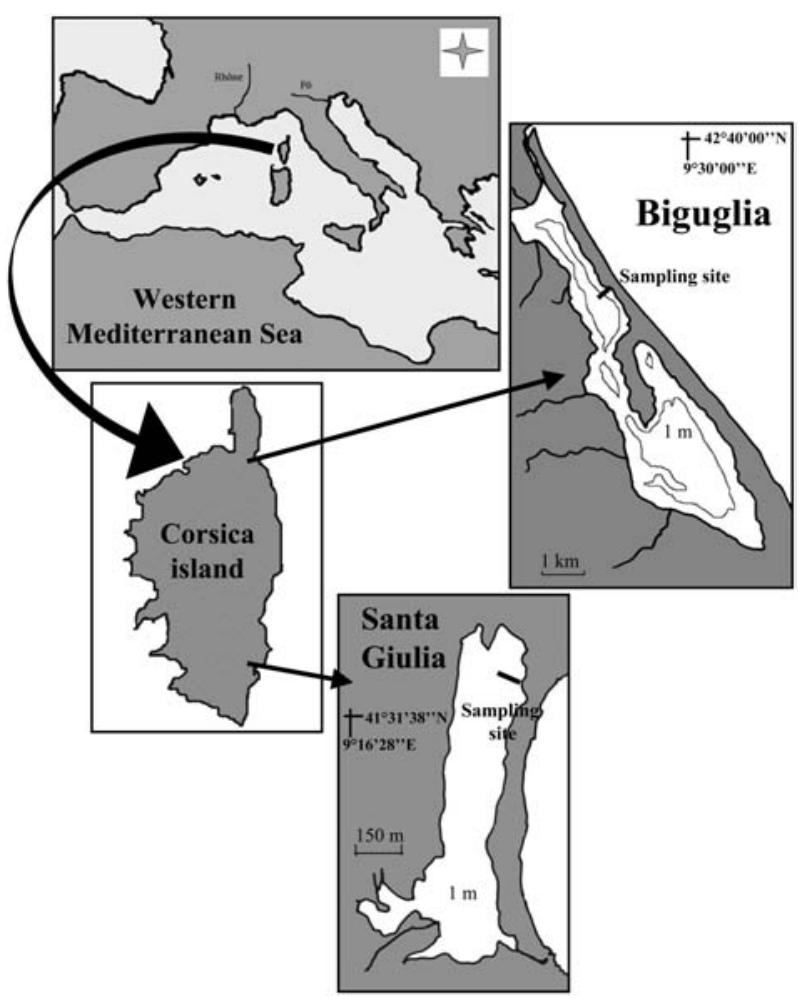

Figure 1 Ruppia cirrhosa: location of Biguglia and Santa Giulia lagoons in Corsica (France) and sampling sites.

most other Mediterranean lagoons (e.g., total nitrogen, ammonium; Orsoni et al. 2001).

The Santa Giulia lagoon (Figure 1) is located on an estate owned by the "Conservatoire de l'espace littoral et des rivages lacustres". This irregularly shaped lagoon is separated from the sea by a narrow sandy strand exposed to strong erosion since 1986 (Gauthier 1992). It is a mesohaline lagoon (Sacchi 1985, Table 1) with a temporary channel located to the south of the sandy beach. The bottom is constituted mainly of silty sediments
(Lorenzoni et al. 1993). This lagoon is subjected to tourist pressures in summer.

Monitoring of the vegetation was carried out using the transect technique (Corre 1970), with fixed markers set up in July 1997, and checked regularly thereafter. After preliminary studies, the transects (each $100 \mathrm{~m}$ long; Figure 1) were set up in the two lagoons in areas where seagrass beds were representatives (coverage, distribution, species; Figure 1). Spatio-temporal changes in seagrasses were investigated by recording the plant populations $1 \mathrm{~m}$ on either side of these markers for microcartography (precision $20 \mathrm{~cm}$ ). Presence/absence, cover and health estimation (dead, alive) of populations were recorded along transects. Cover was estimated in four classes: 0-25, 25-50, 50-75 and 75-100\%. In parallel, from July 1997 to July 1999, a systematic sampling was done at each sampling station parallel to the transect $(5$ replicates, every $20 \mathrm{~m})$. A cylindrical corer $(15 \mathrm{~cm}$ diameter $\times 50 \mathrm{~cm}$ long) was pushed up to $20 \mathrm{~cm}$ into the sediment in monospecific stands (5 replicates), in order to follow seasonal variations of Ruppia cirrhosa. For each core, shoots of $R$. cirrhosa were counted (density per $\mathrm{m}^{2}$ ), and the aboveground biomass (foliar shoots) and the belowground biomass (rhizomes and roots) were weighed after oven drying $\left(48 \mathrm{~h}\right.$ at $\left.60^{\circ} \mathrm{C}\right)$. Organic matter content of the sediment was measured in the surface layer $(0-10 \mathrm{~cm})$ by weighing the ash after combustion in a muffle furnace $\left(3 \mathrm{~h}\right.$ at $\left.500^{\circ} \mathrm{C}\right)$. Also, at the Biguglia lagoon, when presence of Ulvophyceae was observed, its cover and biomass were estimated by sampling the species in a $0.4 \mathrm{~m}^{2}$ quadrat near each sampling station of $R$. cirrhosa.

Comparisons of parameters as a function of site or season were processed by paired $t$-tests or KruskalWallis tests, coupled with a Student-Newmann-Keuls test, in order to detect significant differences (Zar 1984). The relation between two parameters was analysed using a simple linear regression (Zar 1984). The software Statgraphics plus (v 2.1) for Windows was used.

Table 1 Ruppia cirrhosa: main characteristics of the Biguglia and Santa Giulia lagoons.

\begin{tabular}{lll}
\hline & Biguglia & Santa Giulia \\
\hline Abiotic parameters & & \\
Geographical coordinates & $42^{\circ} 37^{\prime} \mathrm{N}, 9^{\circ} 27^{\prime} \mathrm{E}$ & $41^{\circ} 31^{\prime} \mathrm{N}, 9^{\circ} 15^{\prime} \mathrm{E}$ \\
Surface area (ha) & 1500 & 26 \\
Maximum depth $(\mathrm{m})$ & 1.8 & 1.0 \\
Mean depth $(\mathrm{m})$ & 1.5 & 0.5 \\
Catchment area $\left(\mathrm{km}^{2}\right)$ & 180 & 15.5 \\
Water residence time (month) & $1-2$ & 1 \\
Temperature $\left({ }^{\circ} \mathrm{C}\right)$ & $5-26$ & $12-25$ \\
Salinity (psu) & $4-26$ & $12-37$ \\
Human pressure sources & & 712 \\
Population of catchment area (ha) & 18528 & None \\
Industrial and touristic activities in & Effluent, wine making, airport, oil tanks, \\
$\quad$ the catchment area & boilerworks, hotels and restaurants, transport & None \\
Agricultural activities in the & Orchards, vineyards, pumpkins and squashes, stock & Holiday village, \\
$\quad$ catchment area & rearing & hotels and restaurants \\
Activities at the lido & Built-up area, holiday village, hotels and restaurants & None \\
\hline
\end{tabular}

(Data from Pergent-Martini et al. 1997, Orsoni et al. 2001). 


\section{Results}

Vegetation distribution along the transects differed according to season and site. In winter, Ruppia cirrhosa was dormant as short quiescent leaf-bearing stolons, which prevented monitoring the transects. At Biguglia, a healthy continuous and rather dense meadow of $R$. cirrhosa was observed (about $50 \mathrm{~m}$ off shore) in July 1997 and in April 1998, with presence of Ulva specimens (Figure 2). In July, $R$. cirrhosa was replaced by members of the Ulvophyceae that can, locally, constitute very dense formations that form detached free-floating mats near the bottom, with heights up to $20-30 \mathrm{~cm}$ (continuous beds of Ulva species, from $35 \mathrm{~m}$ to $75 \mathrm{~m}$ from shore; 1324 to $2983 \mathrm{~g} \mathrm{~m}^{-2}$; Figure 2). This continuous meadow of $R$. cirrhosa disappeared almost entirely during this period, with mortalities of $R$. cirrhosa and Ulva species. Later, $R$. cirrhosa appeared again with high cover in spring 1999 and Ulva species decreased drastically (2 to $162 \mathrm{~g} \mathrm{~m}^{-2}$; Figure 2). Seagrass was then much more developed than the previous year and it occupied almost the whole transect. At Santa Giulia in April 1998, a sparse meadow of $R$. cirrhosa was observed on silt, and this meadow became continuous $45 \mathrm{~m}$ off shore (Figure 2). Over the whole study period, the only variations were in meadow cover (Figure 2).

Shoot density of Ruppia cirrhosa meadows varied, on average, from $3316 \pm 1112$ shoots $\mathrm{m}^{-2}$ (Biguglia, July 1998 ) to $16401 \pm 3657$ shoots $m^{-2}$ (Santa Giulia, October 1997; Figure 3A). Density variations occurred over the study period at both sites (Kruskal-Wallis test, $p<0.05$ ). Maximal densities for Biguglia were recorded in April 1998 and for Santa Giulia in July 1997 (SNK test, $\mathrm{p}<0.05$ ). However, no seasonal pattern was observed. For each site, the average density was higher in the first year (July 1997-July 1998) than in the second year (July 1998-July 1999; SNK test, $\mathrm{p}<0.05$ ). Comparison between sites shows that $R$. cirrhosa densities were generally significantly higher in the Santa Giulia lagoon (paired $t$-test, $\mathrm{p}<0.05$; Figure $3 \mathrm{~A}$ ).

Ruppia cirrhosa aboveground biomass varied from $8 \pm 4 \mathrm{~g} \mathrm{DW} \mathrm{m}^{-2}$ (Biguglia, October 1998) to $343 \pm 70$ g DW m-2 (Biguglia, July 1999; Figure 3B). For the two sites studied, significant seasonal variations were observed (Kruskal-Wallis test, $p<0.05$ ), with an increase of biomass in spring and summer, and a decrease in autumn and winter (SNK test, $p<0.05$ ). Significant differences between years were observed in April (higher in 1998) and July (higher in 1997 and 1999) for the two sites studied. Comparison of the two sites shows significant variations with a greater aboveground biomass at Santa Giulia than at Biguglia, except in July 1997 and 1999 when the reverse pattern was observed (paired $t$-test, $p<0.05$ )

The belowground biomass varied from $4 \pm 2 \mathrm{~g} \mathrm{DW} \mathrm{m}^{-2}$ (Biguglia, October 1998) to $87 \pm 15 \mathrm{~g} \mathrm{DW} \mathrm{m}^{-2}$ (Santa Giulia, October 1997; Figure 3C). The variations observed for the study period were significant (Kruskal-Wallis test, $p<0.05$ ), even though no seasonal pattern was observed. Biomass was higher in the period July 1997-April 1998 than in the period July 1998-July 1999. In the same way, no significant difference was recorded between the two sites (paired $t$-test, $\mathrm{p}>0.05$ ). The aboveground: belowground biomass ratio (AB:BB ratio, Figure $3 \mathrm{D}$ ) confirms the seasonal trends observed for both lagoons, but highlights an important difference in biomass allocation in July 1998 between the sites. The AB:BB ratio was significantly higher in Santa Giulia (26.21) than in Biguglia (11.39).

Organic matter content in the Ruppia cirrhosa meadows sediment varied from 1.6\% (Biguglia, January 1998) to 4.6\% (Santa Giulia, July 1999; Figure 4) and differed among sampling times. At Santa Giulia, the organic matter content increased significantly from the beginning of 1998 to the end of the study; thus it was higher in the second year than in the first year (Kruskal-Wallis and SNK tests, $\mathrm{p}<0.05)$. On the other hand, at Biguglia the organic matter content remained steady over the whole period of study, except in April 1998 which showed a significantly higher content than the other months (Kruskal-Wallis and SNK tests, $p<0.01$ ). Statistical analysis of the results shows that, except in April 1998, the organic matter content was lower in Biguglia than in Santa Giulia (paired $t$-test, $\mathrm{p}<0.05$ ). No correlation between the organic matter content in the sediment and the total biomass or the belowground biomass was observed (correlation test, $0.07<r<0.37 ; \mathrm{p}>0.05$ ).

\section{Discussion}

Our results on density, aboveground and belowground biomasses are concordant with those reported in the literature (Verhoeven 1980, Bachelet et al. 2000, Calado and Duarte 2000, Azzoni et al. 2001, Menéndez 2002). In particular, the total biomass values at both sites (Biguglia and Urbino) are higher than values observed in the Ebro Delta (Spain; Menéndez 2002) and comparable with those recorded for the Santo André lagoon (Portugal; Calado and Duarte 2000).

The biotic parameters of the two populations of Ruppia cirrhosa showed seasonal variations. Higher aboveground biomass (attributable to larger leaves) in summer is well known for this species (Verhoeven 1980, Bachelet et al. 2000, Azzoni et al. 2001, Menéndez 2002). These variations in biomass of magnoliophytes seem to be linked to the strong variations in temperature and light over the year (Duarte 1989, Perez-Llorens and Niell, 1993, Laugier et al. 1999). Biguglia and Santa Giulia lagoons have strong variations in temperature (Figure $5 \mathrm{~A}$ ), and a significant correlation between aboveground biomass and temperature was observed $(r=0.69$, $\mathrm{p}<0.05$ ).

Comparison between the two populations of Ruppia cirrhosa (Biguglia and Santa Giulia) reveals the following differences: (i) a smaller density and aboveground biomass at Biguglia and (ii) more variation in cover at Biguglia. These results could be related to differences in nutrient availability due to inputs of nutrients in each lagoon (Figure 5B-E). The correlation matrix shows a significant correlation between aboveground biomass and ammonium, nitrates (correlation test, $r=-0.57$ and -0.54 , respectively, $p<0.05$ ), and between density and phosphates (correlation test $\mathrm{r}=0.52, \mathrm{p}<0.05$ ). Important 
A
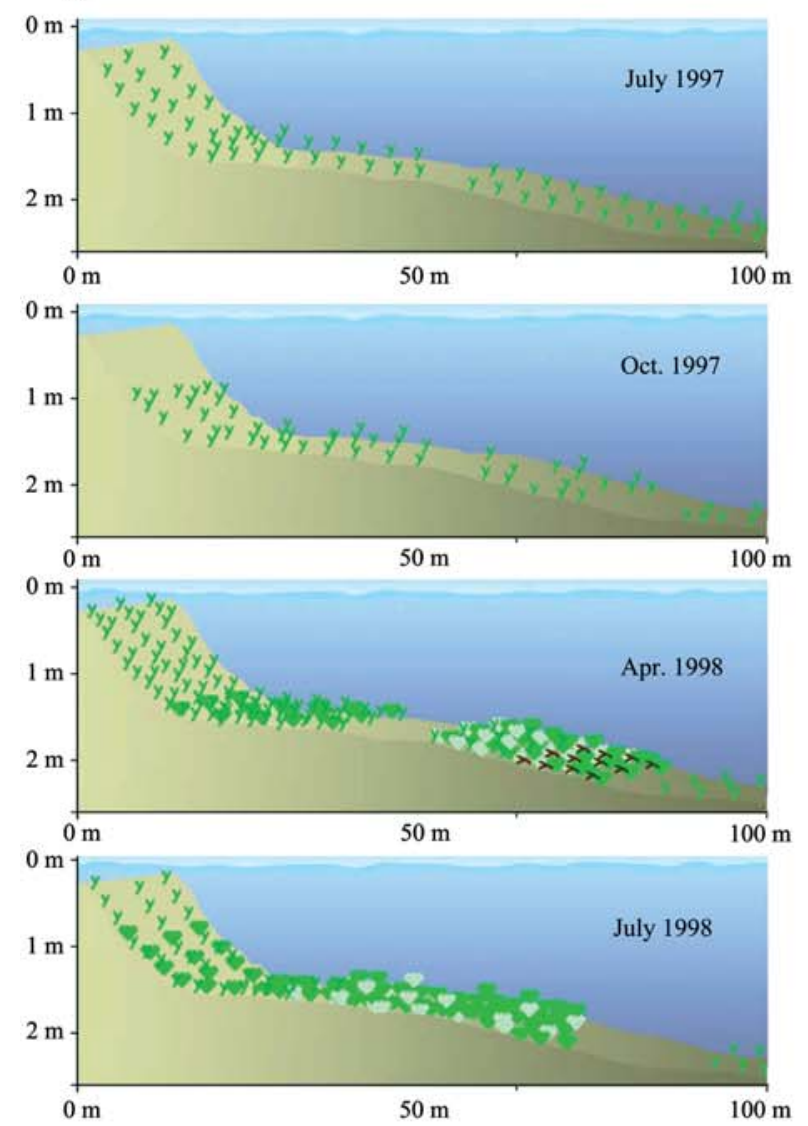

B
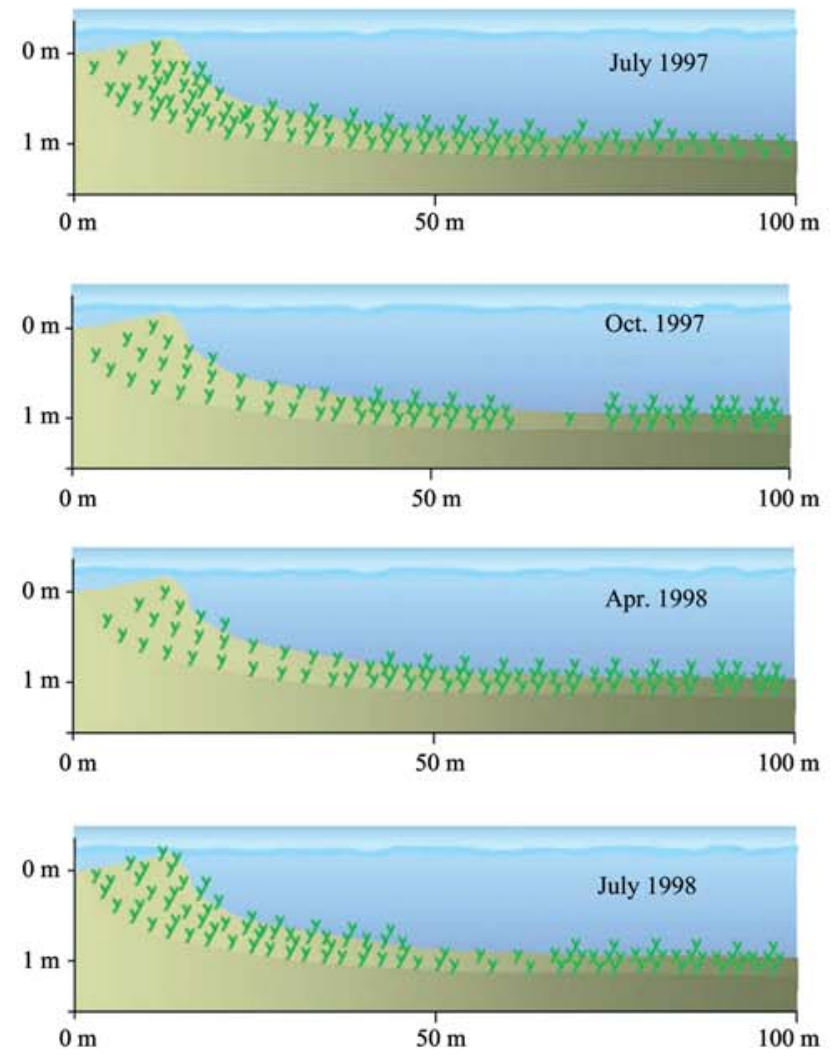
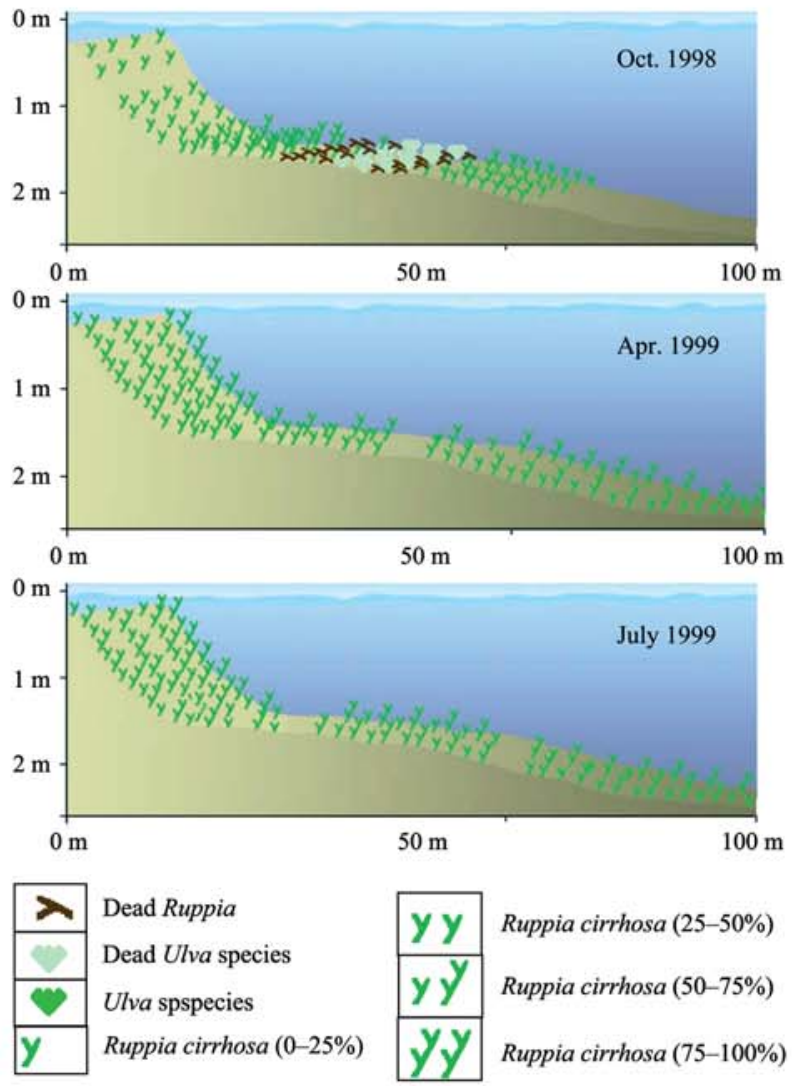
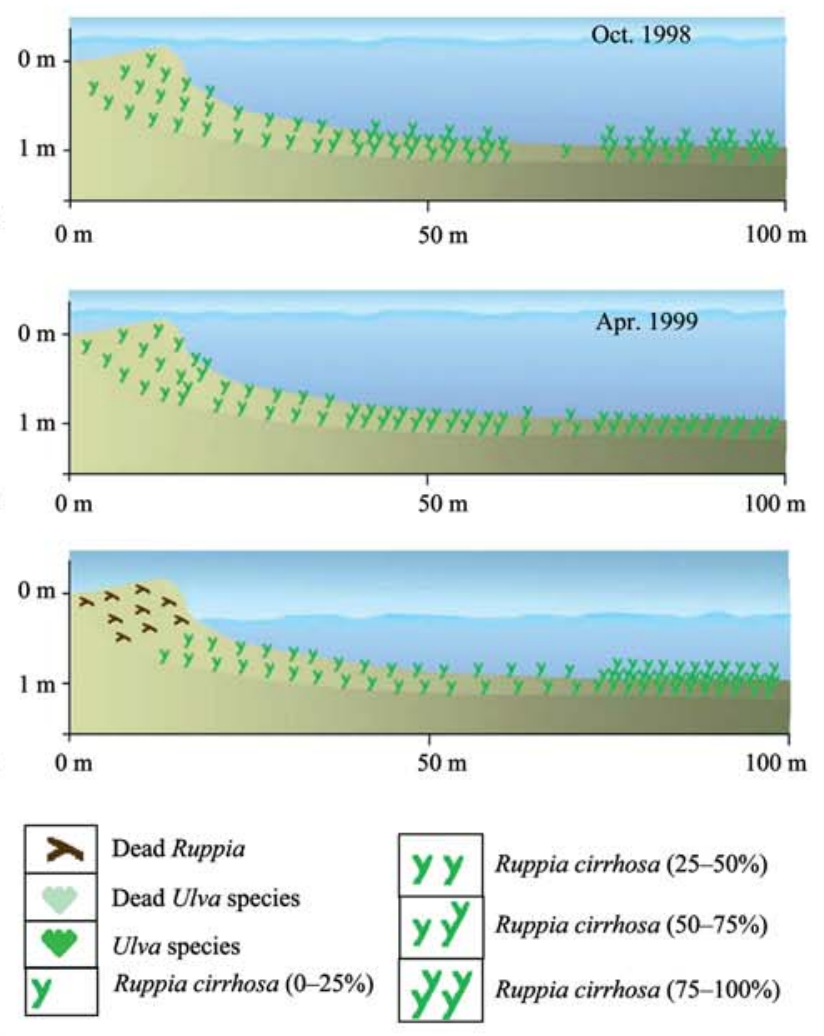

Figure 2 Ruppia cirrhosa: vegetation cover monitoring along permanent transects in Biguglia (A) and Santa Giulia (B) lagoons. 


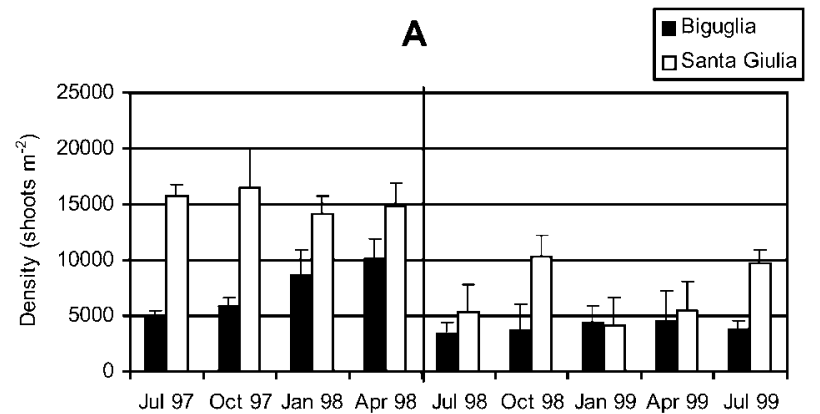

C

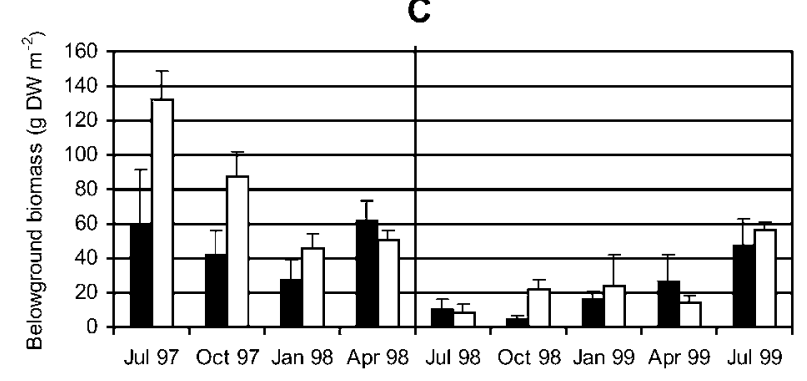

B

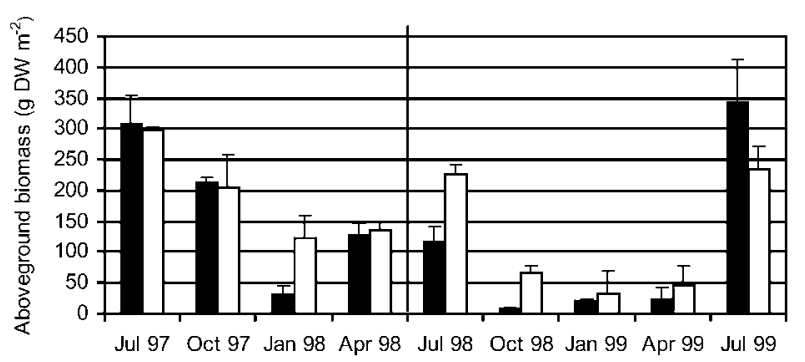

D

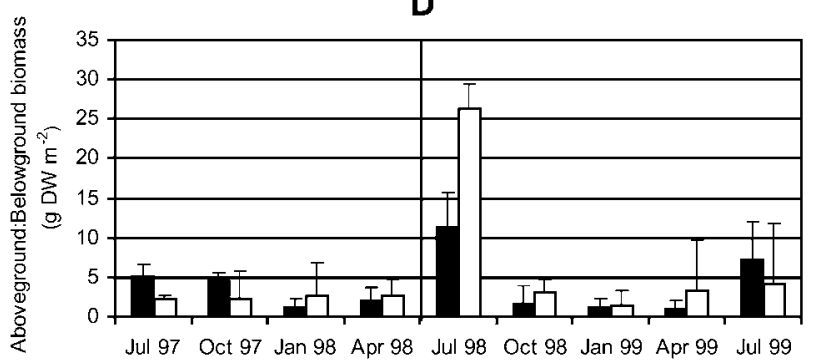

Figure 3 Ruppia cirrhosa: seasonal variations of density (A), aboveground biomass (B), belowground biomass (C), and ratio aboveground:belowground biomass (D) in Biguglia and Santa Giulia lagoons (mean and 95\% confidence interval).

inputs in nutrients could cause negative indirect effects on the magnoliophytes through proliferation of plankton or macroalgal blooms (Sfriso et al. 2003). In Biguglia, observations of the green macroalgal bloom (Ulva species) in spring and summer 1998 reveal environmental modifications in the sampling site with a probable increase in nutrients in the water column, and an increase in organic matter in the sediment which could be related to significant rainfall at this site in March and April 1998 (compared to Santa Giulia and to 1999). These modifications seem to allow the development of macroalgae and to limit magnoliophyte development at this location. Macroalgae, such as members of the Ulvophyceae, are able to absorb large quantities of nutrients, eventually producing sudden blooms. These species are primarily nitrogen-limited and stimulated by the loading provided by waste discharge (Giusti and Marsilli-Libelli 2005). These data seem to describe a dystrophic crisis in the Biguglia lagoon in spring-summer 1998, as described by Viaroli et al. (1996). These crises are often caused by the combination of nutrient input, high temperature, high oxygen consumption, long periods of calm winds and subsequent reduction in water exchange (Orsoni et al. 2001), which generate a proliferation of opportunistic macroalgae (Bachelet et al. 2000). This proliferation leads to a decrease in light intensity received by the magnoliophytes (Da Silva and Asmus 2001). The Biguglia lagoon is eutrophic because of agricultural runoff and wastewater discharge. The environmental modifications observed at the sampling site of this lagoon during spring-summer 1998 were confirmed by the mortality of $R$. cirrhosa. Algal decomposition may also generate an anoxic phenomenon harmful to the development of the magnoliophytes (Giusti and Marsili-Libelli 2005). Light attenuation and decomposition of macroalgae following collapse of the bloom have strong effects on $R$. cirrhosa meadows (drop in biomass and densities). The phenomenon of macroalgal proliferation, which led to the regression of $R$. cirrhosa, has been observed in other Mediterranean lagoons (Viaroli et al. 1996, Bachelet et al.

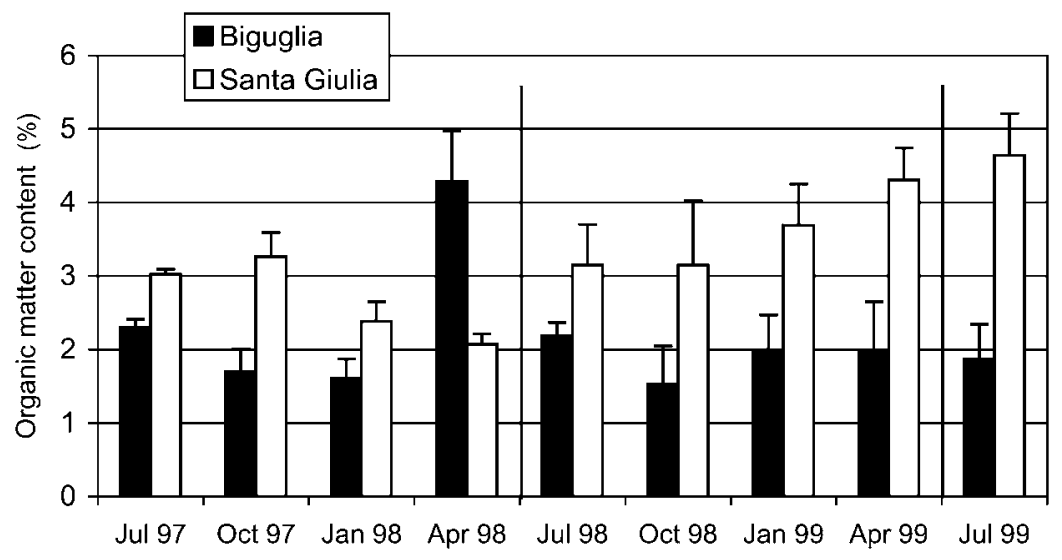

Figure 4 Ruppia cirrhosa: seasonal variations of sediment organic matter in Biguglia and Santa Giulia lagoons (mean and 95\% confidence interval). 


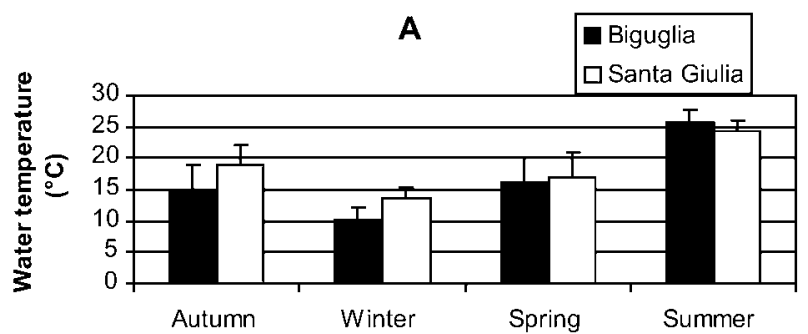

B

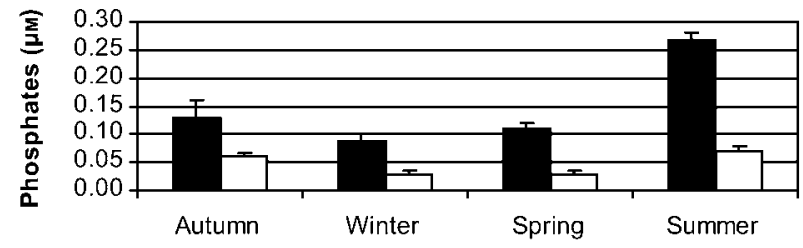

D

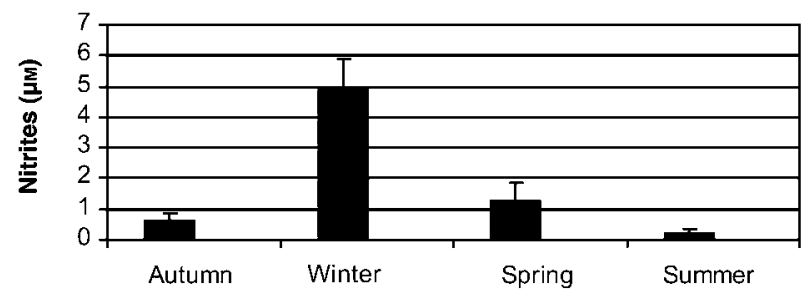

C

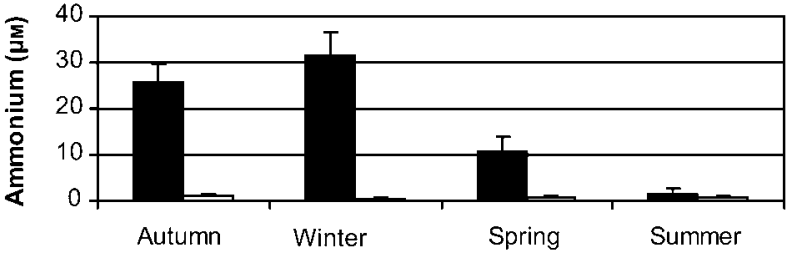

$\mathbf{E}$

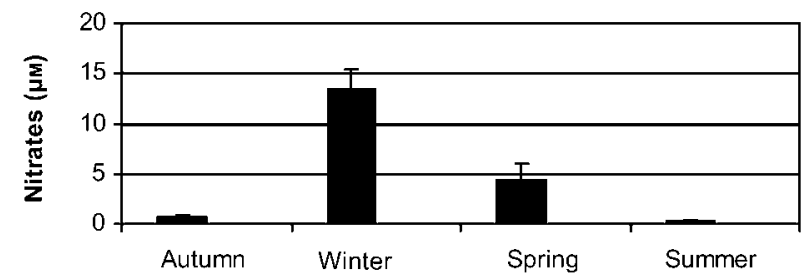

$\mathbf{F}$

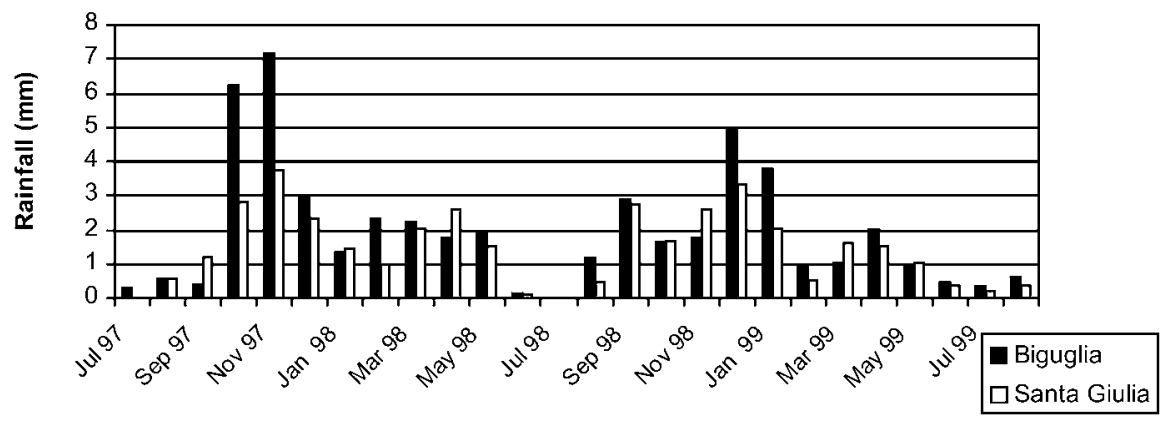

Figure 5 Ruppia cirrhosa: seasonal variations of water temperature (A), phosphates (B), ammonium (C), nitrites (D), nitrates (E), and rainfall $(F)$ in Biguglia and Santa Giulia lagoons.

Data for water temperature, phosphates, ammonium, nitrites and nitrates were obtained from September 1998 to September 1999 for Biguglia lagoon (Orsoni et al. 2001) and from September 1994 to September 1995 for Santa Giulia lagoon (Canovas et al. 1996). The data for Santa Giulia come from a nearby lagoon with similar characteristics (personal com. G.F. Frisoni). Rainfall data were collected between July 1997 and August 1999 (MétéoFrance ${ }^{\circledR}$ ) for the two lagoons.

2000, Mistri et al. 2000). Indeed, the differing physiological requirements of the algae and magnoliophytes tend to produce a mutual exclusion (Giusti and Marsili-Libelli 2005). This phenomenon was reported for other magnoliophytes (e.g., Zostera marina; Coffaro and Bocci 1997). Comparison of the AB:BB ratio between the sites (Figure 3D) in July 1998 highlights the fact that $R$. cirrhosa meadows at Biguglia are not able to develop as much aboveground tissues as populations of Santa Giulia. Indeed, the presence of high densities of macroalgae in Biguglia leads $R$. cirrhosa to invest its biomass in subterranean tissues at the expense of photosynthetic tissues.

These density and biomass results could be also related to differences in nutrient availability in the sediment. The high concentrations of organic matter at the sampling site in Santa Giulia lagoon seem to constitute an important source of nutrients, which may improve Ruppia cirrhosa growth. Sediment composition appears to have a primary influence on establishment and development of Ruppia meadows (Guisti and Marsili-Libelli 2005). The amount of nutrients being supplied by organic matter is a positive factor supporting plant growth, as has already been shown for Zostera marina (Kenworthy and Fonseca 1992, Van Lent et al. 1995, Peralta et al. 2003). These organic matter concentrations must be carefully measured and considered with care, because an excess of organic matter can cause anoxic events in the sediment by mineralisation, and release of hydrogen sulphide with consequent negative effects on plants (Tagliapietra et al. 1998).

Annual comparisons (1997-1998, 1998-1999) for both sites (Biguglia and Santa Giulia) show higher values in 1997-1998 for the whole set of parameters measured, together with the development of macroalgae in the sam- 
pling site of Biguglia. The available rainfall data (Meteo France ${ }^{\circledR}$ data; Figure 5F) indicate that both lagoons benefited from higher inputs of fresh water, which came from their catchment areas in 1997-1998. This could have led to a better mixing of the water and to an enrichment in nutrients able to support the development of Ruppia cirrhosa plants (high density and biomass values for that period) and, in some cases, of macroalgae.

Presence of anthropogenic stresses causing environmental parameter variations in some Corsican lagoons affects the functioning Ruppia cirrhosa meadows. Even if this species shows a high resistance to variations in environmental conditions and resilience capacity (sensu Connell and Sousa 1983), nutrient input by human activities could jeopardise the future survival of the meadows by facilitating the development of other more opportunistic species.

\section{Acknowledgements}

This work was carried out under, and funded by, the Programme National d'Océanologie Côtière (PNOC) in partnership with IFREMER and the French Ministry of the Environment, for the valorisation of Mediterranean lagoons. Some of the results were acquired from the European Life and Interreg programmes. The authors would like to thank O. Dumay, J.E. Tomaszewski and C. Segui for their participation in field missions and M. Paul for help with the English translation. The authors also greatly appreciate comments provided by the editor and the reviewers.

\section{References}

Agenc. 1989. Etang de Biguglia, Haute Corse. Dossier scientifique, propositions pour la création d'une réserve naturelle. Rapport Agenc, lare, Srae et Club Ornithologique Association des amis du PNRC, France. pp. 96.

Agostini, S., A. Capiomont, B. Marchand and G. Pergent. 2003. Distribution and estimation of basal area coverage of subtidal seagrass meadows in a Mediterranean coastal lagoon. Estuar. Coast. Shelf Sci. 56: 1021-1028.

Auby, I. and P.J. Labourg. 1996. Seasonal dynamics of Zostera noltii Hornem. in the bay of Arcachon (France). J. Sea Res. 35: 269-277.

Azzoni, R., G. Giordani, M. Bartoli, D.T. Welsh and P. Viaroli. 2001. Iron, sulphur and phosphorus cycling in the rhizosphere sediments of a eutrophic Ruppia cirrhosa meadow (Valle Smarlacca, Italy). J. Sea Res. 45: 15-26.

Bachelet, G., X. De Montaudouin, I. Auby and P.J. Labourg. 2000. Seasonal changes in macrophyte and macrozoobenthos assemblages in three coastal lagoons under varying degrees of eutrophication. ICES J. Mar. Sci. 57: 1495-1506.

Bacher, C., H. Bioteau, and A. Chapelle. 1995. Modelling the impact of a cultivated oyster population on the nitrogen dynamics: the Thau lagoon case (France). Ophelia 42: 29-54.

Baroli, M., V. Bombelli, M. Lenzi and G. Piergallini. 1997. Ricerche ecologiche nella laguna di s'ena arrubia (sardegna occidentale), variazioni stagionali della composizione delle principali associazioni vegetali e della biomassa delle specie dominanti. Biol. Mar. Medit. 4: 463-465.

Bettinetti, A., P. Pypaert and J.P. Sweerts. 1996. Application of an integrated management approach to the restoration project of the lagoon of Venice. J. Environ. Manag. 46: 207-227.

Blandin, P. 1986. Bioindicateurs et diagnostic des systèmes écologiques. Bull. Ecol. 17: 211-307.
Boulmer, M., C. Lorenzoni and C. Cantera. 1997. Plan de gestion de la réserve naturelle de Biguglia. Conseil Général de la Haute-Corse, France. pp. 243.

Canovas, S., S. Sancho and E. Dutrieux, 1996. Diagnostic hydrologique et hydrobiologique de l'étang de Palo, Corse. Rapport IARE réalisé pour le compte du Conservatoire du littoral et de l'Agence de l'Eau RMC, France. pp. 155.

Coffaro, G. and M. Bocci. 1997. Resources competition between Ulva rigida and Zostera marina: a quantitative approach applied to the Lagoon of Venice. Ecol. Mod. 102: 81-95.

Connell, J.H. and W.P. Sousa. 1983. On the evidence needed to judge ecological stability or persistence. Am. Nat. 121: 789-824.

Corre, J. 1970. La méthode des transects dans l'étude de la végétation littorale. Bull. Acad. Soc. Lorraine Sci. 9: 59-79.

Da Silva, E.T. and M.L. Asmus. 2001. A dynamic simulation model of the widgeon grass Ruppia maritima and its epiphytes in the estuary of the Patos Lagoon, RS, Brazil. Ecol. Mod. 137: 161-179.

De Casabianca, M.L., T. Laugier and D.Collart. 1997. Impact of shellfish farming eutrophication on benthic macrophyte communities in the Thau lagoon, France. Aquacult. Int. 5: 301-314.

Deslous-Paoli, J.M., P. Souchu, N. Mazouni, C. Juge and F. Dagault. 1998. Relationship between environment and resources: impact of shellfish farming on a Mediterranean lagoon (Thau, France). Oceanol. Acta 21: 831-843.

Duarte, C.M. 1989. Temporal biomass variability and production/ biomass relationships of seagrass communities. Mar. Ecol. Progr. Ser. 51: 269-276.

Duarte, C.M., R. Martinez and C. Barron. 2002. Biomass, production and rhizome growth near the northern limit of seagrass (Zostera marina) distribution. Aquat. Bot. 72: 183-189.

Frisoni, G.F. and E. Dutrieux. 1992. L'étang de Biguglia - diagnostic écologique 1991-1992. Rapp. lare, France. pp. 167.

Guilizzoni, P. 1991. The role of heavy metals and toxic materials in the physiological ecology of submersed macrophytes. Aquat. Bot. 41: 87-109.

Giusti, E. and S. Marsili-Libelli. 2005. Modelling the interactions between nutrients and the submersed vegetation in the Orbetello Lagoon. Ecol. Model. 184: 141-161.

Kenworthy, W.J. and M.S. Fonseca. 1992. The use of fertilizer to enhance growth and transplanted seagrass Zostera marina L. and Halodule wrightii Aschers. J. Exp. Mar. Biol. Ecol. 16: $141-161$.

Kjerfve, B. 2000. Coastal lagoon processes. Elsevier Oceanography Series, Amsterdam. pp. 577.

Laugier, T., V. Rigollet and M.L. De Casabianca. 1999. Seasonal dynamics in mixed eelgrass beds, Zostera marina $L$. and $Z$. noltii Hornem., in a Mediterranean coastal lagoon (Thau lagoon, France). Aquat. Bot. 63: 51-69.

Lorenzoni, C., J.M. Gehu, C. Lahondere and G. Paradis. 1993. Description phytosociologique et cartographique de la végétation de l'étang de Santa Giulia (Corse du Sud). Bull. Soc. Bot. Centre-Ouest 24: 121-150.

Marzano, C.N., L.S. Liaci, A. Fianchini, F. Gravina, M. Mercurio and G. Corrieron. 2003. Distribution, persistence and change in the macrobenthos of the lagoon of Lesina (Apulia, southern Adriatic Sea). Oceanol. Acta 26: 57-66.

Menéndez, M. 2002. Net production of Ruppia cirrhosa in the Ebro Delta. Aquat. Bot. 73: 1-7.

Menéndez, M., O. Hernandez and F.A. Comin. 2002. Spatial distribution and ecophysiological characteristics of macrophytes in a Mediterranean coastal lagoon. Estuar. Coast. Shelf Sci. 55: 403-413.

Meriaux, J.L. and J.R. Wattez. 1980. Les végétations aquatiques et subaquatiques. Relations avec la qualité des eaux. In: (P. Pesson, ed.). La pollution des eaux continentales. Incidence sur les biocénoses aquatiques. Gauthier-Villars publ., Paris. pp. 225-242. 
Millet, B. and O. Guelorget. 1993. Relationships between benthic communities and physical environment in a lagoon ecosystem. J. Coast. Res. 9: 378-389.

Mistri, M., E.A. Fano, G. Rossi, K. Caselli and R. Rossi. 2000. Variability in macrobenthos communities in the Valli di Comacchio, Northern Italy, a hypereutrophized lagoonal ecosystem. Estuar. Coast. Shelf Sci. 51: 599-611.

Orsoni, V., P. Souchu and D. Sauzade. 2001. Caractérisation de l'état d'eutrophisation des trois principaux étangs corses (Biguglia, Diana et Urbino), et proposition de renforcement et leur surveillance. Rapport final Ifremer, Ifremer, France. pp. 254.

Pearce, F. and A.J. Crivelli. 1994. Caractéristiques générales des zones humides méditerranéennes. Conservation des zones humides méditerranéennes. Programme MedWet, Fondation Tour du Valat publish., Arles. pp. 89.

Peralta, G., T.J. Bouma, J. Van Soelen, J.L. Perez-Llorens and I. Hernandez. 2003. On the use of sediment fertilization for seagrass restoration: a mesocosm study on Zostera marina $\mathrm{L}$. Aquat. Bot. 75: 95-110.

Perez, M. and J. Romero. 1994. Growth dynamics, production, and nutrient status of the seagrass Cymodocea nodosa in a Mediterranean semi-estuarine environment. PSZNI Mar. Ecol. 15: 51-64.

Pérez-Llorens, J.L. and F.X. Niell. 1993. Seasonal dynamics of biomass and nutrient content in the intertidal seagrass Zostera noltii Hornem. from Palmones river estuary, Spain. Aquat. Bot. 46: 49-66.

Pergent-Martini, C., C. Fernandez, V. Pasqualini, G. Pergent, C. Segui and J.E. Tomaszewski. 2000. Les étangs littoraux de Corse: cartographie des peuplements et types de fonds. Contrat équipe Ecosystèmes Littoraux - Univ. Corse and Ifremer no. 993 514004, France. pp. 34.

Pergent-Martini, C, R. Semroud, V. Rico-Raimondino and G. Pergent. 1997. Localisation et évolution des peuplements de phanérogames aquatiques de l'étang de Berre (Bouches du Rhône, France). In: (Association française de Limnologie, ed.) 39ème congrès nationaux. Corte, France. pp. 169-179.

Philippart, C.J.M. 1995. Seasonal variation in growth and biomass of an intertidal Zostera noltii stand in the Dutch Wadden Sea. Neth. J. Sea Res. 33: 205-218.

Plus, M., J.M. Deslous-Paoli, I. Auby and F. Dagault. 2001. Factors influencing primary production of seagrass beds (Zostera noltii Hornem.) in the Thau lagoon (French Mediterranean coast). J. Exp. Mar. Biol. Ecol. 259: 63-84.

Ribera, G., M. Coloreu, C. Rodriguez Prieto and E. Ballesteros. 1997. Phytobenthic assemblages of Addaia Bay (Menerca, western Mediterranean): composition and distribution. Bot. Mar. 40: 523-532.

Sacchi, C. 1985. Le sel de La Palice: réflexion sur le paralin méditerranéen. Mem. Biol. Mar. Oceanogr. 15: 71-89.

Sfriso, A. and P.F. Ghetti. 1998. Seasonal variation in biomass, morphometric parameters and production of seagrasses in the lagoon of Venice. Aquat. Bot. 61: 1-17.
Sfriso, A., T. Birkemeyer and P.F. Ghetti. 2001. Benthic macrofauna changes in areas of Venice lagoon populated by seagrasses or seaweeds. Mar. Environ. Res. 52: 323-349.

Sfriso, A., C. Facca and P.F. Ghetti. 2003. Temporal and spatia changes of macroalgae and phytoplankton in a Mediterranean coastal area: the Venice lagoon as a case study. Mar. Environ. Res. 56: 617-636.

Skinner, J. and S. Zalewski. 1995. Fonctions et valeurs des zones humides méditerranéennes. Conservation des zones humides méditerranéennes, Programme MedWet. Fondation Tour du Valat publish., Arles. pp. 78.

Tagliapietra, D., M. Pavan and C. Wagner. 1998. Macrobenthic community changes related to eutrophication in Palude della Rosa (Venetian Lagoon, Italy). Estuar. Coast. Shelf Sci. 47: 217-226.

Tamisier, A. and C.F. Boudouresque. 1994. Aquatic bird populations as possible indicators of seasonal nutrient flow at Ichkeul lake, Tunisia. Hydrobiologia 279/280: 149-156.

Van Lent, F., J.M. Verschuure and M.L.J. Veghel Van. 1995. Comparative study on populations of Zostera marina L. (seagrass): in situ nitrogen enrichment and light manipulation. $J$. Exp. Mar. Biol. Ecol. 185: 55-72.

Verhoeven, J.T.A. 1975. Ruppia communities in the Camargue, France. Distribution and structure in relation to salinity and salinity fluctuations. Aquat. Bot. 1: 217-241.

Verhoeven, J.T.A. 1979. The ecology of Ruppia-dominated communities in western Europe. I. Distribution of Ruppia representatives in relation to their autoecology. Aquat. Bot. 6 : 197-268.

Verhoeven, J.T.A. 1980. The ecology of Ruppia-dominated communities in western Europe. III. Aspects of production, consumption and decomposition. Aquat. Bot. 8: 209-253.

Verhoeven, J.T.A. and W. Van Vierssen. 1978. Structure of macrophyte dominated communities in two brackish lagoons on the island of Corsica, France. Aquat. Bot. 5: 77-86.

Vermaat, J.E. and F.C.A. Verhagen. 1996. Seasonal variation in the intertidal seagrass Zostera noltii Hornem.: coupling demographic and physiological patterns. Aquat. Bot. 52: 259-281.

Viaroli, P., M. Bartoli, C. Bondavalli, R.R. Christian, G. Giordani and M. Naldi. 1996. Macrophyte communities and their impact on benthic fluxes of oxygen, sulphide and nutrients in shallow eutrophic environments. Hydrobiologia 329: 105-119.

Viarioli, P., M. Bartoli, I. Fumagalli and G. Giordani. 1997. Relationship between benthic fluxes and macrophyte cover in a shallow brackish lagoon. Water Air Soil Poll. 99: 533-540.

Zar, J.H. 1984. Biostatistical analysis. 2nd edition. Prentice-Hall International Editions, Englewood Cliffs. pp. 718. 